\title{
Do Foreign Exchange Markets Still Trend?
}

\author{
Kuntara Pukthuanthong-Le, ${ }^{a, *}$ Richard M. Levich, ${ }^{b}$ and Lee R. Thomas III ${ }^{c}$ \\ a Corresponding author \\ San Diego State University, College of Business Administration \\ San Diego, CA 92182-8230, USA \\ E-mail: kpukthua@mail.sdsu.edu; Tel: +1-619-594-5690; Fax: +1-619-594-3272 \\ ${ }^{b}$ New York University, Leonard M. Stern School of Business \\ 44 West $^{\text {th }}$ Street New York, NY 10012-1126, USA \\ E-mail: rlevich@stern.nyu.edu; Tel: +1-212-998-0422; Fax: +1-212-995-4220 \\ ${ }^{c}$ Allianz Global Investors \\ Four Embarcadero Center, San Francisco, CA 94111-4189, USA \\ E-mail: lee.name@gmail.com; Tel: +1-512-673-7802
}

Draft: November 13, 2006 


\title{
Do Foreign Exchange Markets Still Trend?
}

\begin{abstract}
Is it possible to profitably trade trends in foreign currencies? We examine the major currency futures contracts which have been trading since the 1970s as well as more recent contracts on exotic currencies that have only begun to trade in the past few years. The main conclusion is that the era of easy profits from simple trend following strategies in major foreign currencies is over. The markets have adapted to the extent that profits from these simple trading strategies have vanished. Presumably, trending may be a feature confined to currencies in the early years of a floating rate regime. When we look at some newly trading currencies, we see more attractive profit opportunities. Newly trading currency futures prices, like their counterparts thirty years ago, appear susceptible to trend following trading strategies.
\end{abstract}




\section{INTRODUCTION}

Most modern financial markets are weak form efficient: it is impossible to forecast future price changes using past price changes. For many years, however, the major spot currency exchange rates and their associated futures prices were anomalies that produced profits when trend following rules were applied to them. ${ }^{1}$ Possibly as a result, currency traders are known to rely heavily on some form of technical models. ${ }^{2}$

The widespread use of technical analysis calls into question the effectiveness of employing trend following models in order to trade currency markets. We would expect that profits on overused strategies tend to fall regardless of the product or market in question. With so many people using similar models, will these models continue to produce profits? How are trend following rules faring in the foreign exchange market?

\section{DATA AND METHODOLOGY}

To address such questions we collected futures settlement data on all the major currencies, pre-1975 to mid-2006. ${ }^{3}$ We use futures rather than spot data because changes in spot rates are only one component of the profit and loss on a currency trade. Because a foreign exchange trade involves two currencies - one bought and one sold - it is crucial to consider the interest received on the long currency and the funding cost of the short currency when calculating profits. Futures market prices do this automatically.

We divide our sample of major currency data into four parts: (1) The early data representing the first 20 years of foreign exchange trend following (1975 to 1994); (2) A comparison of trendbased trading profits in the late 1990s; (3) Conclusion and comments on the performance of trend

following rules since the late 1990s; (4) Conclusion and comments based on the most recent data (2000 to mid-2006).

The data we use are the daily foreign exchange futures contract settlement prices on the near contract, spliced into a single series, extracted from Bloomberg. ${ }^{4}$ All currency futures are traded on 
the Chicago Mercantile Exchange (CME).

We employ three moving averages to produce trading signals (where a signal of +1 represents a long position in the currency, -1 a short position). The first compares the 5-day average with the 20-day average, the second compares the 1-day moving average with the 5-day moving average, and the last compares the 20-day average to the 200-day average in order to pick up long swings in exchange rates. ${ }^{5}$ We buy when the short term average is greater than the long term average and hold the position until the signal changes. All trades occur at settlement prices, where care has been taken to assure that a purchase or sale cannot occur until the trading day following the production of a trading signal. ${ }^{6}$

\section{EMPIRICAL RESULTS}

The data for six individual currency futures contracts, as well as a portfolio of all six, are shown in Exhibit 1 for each of three sub-periods, where returns in US\$ are annualized and expressed in excess of U.S. T-bills so that they can be easily considered in the context of normal risk premiums. As such, a 3 percent return means T-bills plus 3 percent, or a total return of between 7 percent and 8 percent at today's rates. We have assumed that the investor uses enough leverage to produce a volatility of returns of 12 percent, or the approximate volatility of the S\&P 500, which produced an annualized return (in excess of the T-bill rate) of about 3 percent from the beginning of futures trading to the present. Volatility is computed as a standard deviation of the daily returns multiplied by square root 250 . For each currency, volatility is computed for each year and used to determine leverage next year; then volatility is re-estimated on a rolling basis. Daily returns are the difference of natural log of future prices multiplied by the signal varying between +1 and -1 , depending on the values of the individual rules. The returns of a portfolio are an equally-weighted average of all six currencies and have lower volatility as a result of imperfect correlation among the six currencies. The results for major dollar exchange rates and their portfolio are shown in Exhibit 1.

***Please insert Exhibit 1 about here *** 
As the data in the exhibit show, trend following models performed very well until 1995. The equally-weighted portfolio of currencies produced a return of 10.26 percent above T-bills. With volatility of 12 percent, the performance translates into an information ratio of 0.86 .

Since 1995, profits for all currencies have declined and more than half have been negative, results even worse than could be expected from chance alone. The only currency with substantial profits following 1995 is the Japanese yen, and the yen’s profit vanished after 2000. During 19952006, there have been substantial profits for one period each in the yen and the euro, with small gains and losses for other currencies. Overall, looking at an equally weighted portfolio, the post1995 performance of trend following rules is poor. An equally weighted portfolio of currencies using trending rules lost money during 1995-1999 and again 2000-2006.

What happened? One explanation could be that traders have adjusted to exchange rate trends, altering their strategies to reflect the popularity of trend following. Profits may have vanished because traders, anticipating a trend, all try to initiate their positions simultaneously, resulting in a step function response in the currency to news rather than a smooth, trending response. In such a scenario, only the first and quickest traders would make money. Another explanation could be that the "dumb money," which had never previously recognized exchange rate trends and had systematically lost money in these markets, finally got smart, too. At any rate, in 1995-1999 and certainly by the post-2000 period, it was no longer possible to earn profits using moving average trend following trading rules in the major dollar currencies. ${ }^{7}$

We then decided to examine the cross exchange rates to see if a similar phenomenon of profit declines occurred. We wondered if, for example, the Japanese yen against the euro, still allowed trend trading profits despite what was observed in the dollar exchange rate markets. But the results we found were similar to the dollar exchange rate markets: early profits followed by lacklustre performance.

As an example, Exhibit 2 shows the results for the yen/euro cross exchange rate (constructed by multiplication of the dollar futures prices.) The results are similar to dollar exchange rates. 
Profits were substantial in the early days of trend following, but have declined virtually to insignificance during the late 1990s and post-2000. In the case of the yen/euro cross rate the trading rules produced losses since 1995.

$* * *$ Please insert Exhibit 2 about here $* * *$

Of course this is only one cross exchange rate among many, but unfortunately this pattern substantial early profits followed by a decline - is typical of the 15 different cross exchange rates we examined. ${ }^{8}$ Our conclusion is that trend traders have little opportunity in major cross exchange rate markets today.

\section{WHAT IS A TREND TRADER TO DO?}

These empirical results suggest that it is unprofitable to use trend trading in the major currencies today. However, this conclusion has not stopped currency traders from using trend following as a major weapon in their arsenal, perhaps only because it had produced superior returns in the past and they have not adapted to the current market environment. Our results seem to indicate that using a counter-trending model (one that assumes exchange rate changes will be reversed in subsequent periods) would be more effective today. Perhaps the prevalence of trend following models in most trading rooms suggests that traders expect trend following profits to return. In our judgment, this is unlikely to occur any time soon. Rather, the markets seemed to have learned and adapted to trend following in the major currencies.

However, as profits from trend following in the major currencies and crosses have eroded, there remains another group of currencies where traders may still hope to apply trend following techniques for profit. New currency futures contracts are developed every year on newly liquid currencies (the “exotics”).

We have applied the basic moving average crossover rules to a collection of five exotic currency futures. The data on these contracts are again taken from Bloomberg. All contracts are traded on the CME. We apply that same three trend following trading rules here as for the major 
currencies. The results are shown in Exhibit 3.

***Please insert Exhibit 3 about here ***

Trend trading the Brazilian real produced profits in every year from 1999 to 2006. Yearly information ratios are generally in excess of 1 , and the overall information ratio was 1.26 (20002006). The real is by far the most profitable currency in our sample. The Mexican peso produced a profit in only 5 of 8 periods, but still produced a satisfying information ratio of 0.5 over the entire seven-and-a-half year period. Nevertheless, it is worth pointing out that the peso made a loss during the 2006 period, which may indicate that this market is maturing. Similar to the peso, the New Zealand dollar produced profits in 5 of 8 periods. Over the entire sample, the simple trend following rules yielded an information ratio of 0.74 . The South African rand produced profits in 6 of 8 periods, with an information ratio of 0.76 for the entire period. However, two of the last three periods produced losses. The Russian ruble has produced profits in little more than half of the years we examined. Nevertheless, its overall information ratio from 2000 to 2006 was almost 1 (and it suffered losses in 2005, perhaps an ominous sign for the future.)

During the entire period (2000 to mid-2006), each of the five exotic currencies produced a profit, although most had one or more years in which they lost money. One solution would be to construct a diversified portfolio. An equally weighted portfolio of the five exotic currencies produced a profit in every year but one, essentially broke even in the one not profitable year, and registered an information ratio of 1.71 for the entire period (2000 to mid-2006), a truly extraordinary figure. The only (minor) loss on the composite portfolio occurred during 2005. However, towards the end of the period (2005 and 2006), the very high profits experienced in previous periods seemed to show signs of decline, suggesting that these exotic currencies might soon become weak form efficient.

To summarize the results for the exotic currencies, we have again normalized the data, notionally applying leverage, to produce a volatility of $12 \%$ for each currency. The annualized returns that result are shown in Exhibit 4 (Exhibit 4 is directly comparable to Exhibit 1). 


\section{CONCLUSIONS}

In the early years of floating exchange rates, the major currency rates versus the US\$ trended, providing an extended opportunity for traders to use technical trend following rules and profit handsomely. The data we presented suggests that it has taken 20 years before trend following profits were substantially eliminated in the major currencies. ${ }^{9}$ Nevertheless, the lack of profits in these simple models has not deterred many foreign exchange traders from continuing to employ technical analysis. Perhaps traders have evolved to utilize more sophisticated technical models, based on more complex relationships or applied at higher frequencies, minute-by-minute or secondby-second. Or perhaps, astute traders have moved to the road less travelled, what we have called the exotic currencies. It may take far less time for the exotics to become weak form efficient. Indeed there is weak evidence they are already producing less return from trend trading than they once did. Nevertheless, the recent trading profits for exotic currencies are still attractive.

This analysis poses some perplexing dilemmas. First, why did it take 20 years for trend following profits to be eliminated in the major dollar exchange rates? Second, and more relevant to the practical trader, is how long we can expect the exotic currencies to continue to trend now that the positive results of speculating in them have been documented and published? 


\section{ENDNOTES}

1 See Dooly and Shafer [1983], Sweeney [1986], Levich and Thomas [1993], Olson [2004], Neely, Weller and Dittmar [1997], Chang and Osler [1999], Gencay [1999], LeBaron [1999], and Schulmeister [2006].

${ }^{2}$ In a survey of chief foreign exchange dealers in London, Taylor and Allen [1992] find that 90\% of respondents use some form of technical analysis. A more recent survey by Cheung and Chinn [2001] reveals that $30 \%$ of U.S. foreign exchange traders claim that technical trading best describes their overall trading style. Summarizing these and other surveys, Schulmeister [2006] asserts 30\% to $40 \%$ of foreign exchange traders use technical analysis as their principal tool.

3 Except for the Australian dollar, which began futures trading only in 1987.

${ }^{4}$ For example for the Japanese yen, the Bloomberg symbol jy1 produces the yen near futures series.

5 See Engel and Hamilton [1990].

6 This biases the results somewhat against the trading rules. Allowing same day trading has no material effect on our results.

${ }^{7}$ We have also examined the data using 25 momentum rules. The results are broadly similar to the results for the moving average rules: attractive profits before 1994, followed by a decline, with profitability of trend trading gone following 2000.

${ }^{8}$ The 15 possible cross rates are Canadian dollar per British Pound, Swiss Franc per British Pound, Euro per British Pound, Japanese Yen per British Pound, Australian Dollar per British Pound, Swiss Franc per Canadian dollar, Euro per Canadian Dollar, Japanese Yen per Canadian dollar, Australian Dollar per Canadian Dollar, Euro per Swiss Franc, Japanese Yen per Swiss Franc, Australian Dollar per Swiss Franc, Euro per Japanese Yen, Australian Dollar per Japanese Yen, Australian Dollar per Euro. They are calculated from the parity condition by division of the original dollar prices and represent every possible cross rate that can be derived from the original dollar exchange rate series. They are not directly observed cross rates. 
${ }^{9}$ See Park and Irwin [2005] for similar results in other future market contracts. 


\section{REFERENCES}

Chang, P. H. K., \& Osler, C.L. (1999). Methodical Madness: Technical Analysis and the Irrationality of Exchange-Rate Forecasts. The Economic Journal, 109, 636-661.

Cheung Y.W., \& Chinn, M.D. (2001). Currency traders and exchange rate dynamics: a survey of the US market. Journal of International Money and Finance, 20, 439-471.

Dooley, M.P., \& Schafer, J. (1983). Analysis of short-run exchange rate behaviour: March 1973 November 1981. In Bigman, D. and T. Taya (eds.) Exchange Rate and Trade Instability, Ballinger, Cambridge, MA.

Engel, C., \& Hamilton, J. (1990). Long Swings in the Dollar: Are They in the Data and Do Markets Know It? American Economic Review, 80, 689-713.

Gencay, R. (1999). Linear, non-linear and essential foreign exchange rate prediction with simple technical trading rules. Journal of International Economics, 47, 91-107.

LeBaron, B. (1999). Technical trading rule profitability and foreign exchange intervention. Journal of International Economics, 49, 125-143.

Levich, R. M., \& Thomas, L.R. (1993). The significance of technical trading rules in the foreign exchange markets: A bootstrap approach. Journal of International Money \& Finance, 12, 451474.

Neely, C., Weller, P., \& Dittmar, R. (1997). Is Technical Analysis in the Foreign Exchange Market Profitable? A Genetic Programming Approach. Journal of Financial \& Quantitative Analysis, 32, 405-426.

Olson, D. (2004). Have trading rule profits in the foreign exchange markets declined through time? Journal of Banking \& Finance, 28, 85-105.

Park, C., \& Irwin, S. (2005). The Profitability of Technical Trading Rules in US Futures Markets: A Data Snooping Free Test. AgMAS Project Research Report No. 2005-04.

Schulmeister, S. (2006). The interaction between technical currency trading and exchange rate fluctuations. Finance Research Letters, 3, 212-233. 
Sweeney, R. J. (1986). Beating the foreign exchange market. Journal of Finance, 41, 163-182.

Taylor, M., \& Allen, H. (1992). The use of technical analysis in the foreign exchange market. Journal of International Money \& Finance, 11, 304-314. 


\section{EXHIBIT 1}

\section{Average Annual Excess Returns Relative to U.S. T-Bills, Leveraged Based on $12 \%$ Volatility}

of Annual Excess Returns and Moving Average Rules

\begin{tabular}{|c|c|c|c|}
\hline & 1975-1994 & 1995-1999 & $2000-2006^{(\mathbf{b})}$ \\
\hline Japanese Yen & $13.94 \%$ & $13.95 \%$ & $-3.91 \%$ \\
\hline Deutsche Mark/Euro & $8.16 \%$ & $-9.47 \%$ & $3.76 \%$ \\
\hline British Pound & $7.46 \%$ & $-14.79 \%$ & $0.10 \%$ \\
\hline Swiss Franc & $6.20 \%$ & $-1.36 \%$ & $-0.08 \%$ \\
\hline Canadian Dollar & $3.28 \%$ & $-2.06 \%$ & $0.35 \%$ \\
\hline Australian Dollar (a) & $0.51 \%$ & $0.15 \%$ & $-2.09 \%$ \\
\hline Portfolio & $10.26 \%$ & $-2.40 \%$ & $-0.59 \%$ \\
\hline
\end{tabular}

(a) AUD sample period begins in 1987.

(b) Through June 2006 


\section{EXHIBIT 2}

Average Annual Excess Returns on Yen/Euro Relative to U.S. T-Bills, Leveraged Based on 12\% Volatility of Annual Excess Returns and Moving Average Rules

\begin{tabular}{lccc}
\hline & $\mathbf{1 9 7 5 - 1 9 9 4}$ & $\mathbf{1 9 9 5 - 1 9 9 9}$ & $\mathbf{2 0 0 0 - 2 0 0 6}$ \\
\hline \multirow{2}{*}{ Mean Return } & $9.60 \%$ & $-9.42 \%$ & $-3.63 \%$ \\
Volatility & $14.90 \%$ & $32.84 \%$ & $8.31 \%$ \\
Information Ratio & 0.64 & -0.29 & -0.44 \\
\hline
\end{tabular}




\section{EXHIBIT 3}

\section{Average Annual Excess Returns on Exotic Currencies Relative to U.S. T-Bills, Leveraged Based on 12\% Volatility of Annual Excess Returns and Moving Average Rules}

\begin{tabular}{|c|c|c|c|c|c|c|c|c|c|}
\hline & 2000-2006 & 1999 & 2000 & 2001 & 2002 & 2003 & 2004 & 2005 & 2006 \\
\hline \multicolumn{10}{|c|}{ Brazilian Real } \\
\hline Mean of profits & $26.60 \%$ & $33.47 \%$ & $14.39 \%$ & $51.91 \%$ & $21.59 \%$ & $41.15 \%$ & $13.33 \%$ & $22.46 \%$ & $15.58 \%$ \\
\hline Volatility of profits & $21.26 \%$ & $23.86 \%$ & $12.28 \%$ & $27.54 \%$ & $33.20 \%$ & $20.76 \%$ & $11.94 \%$ & $16.26 \%$ & $12.61 \%$ \\
\hline Information ratio & 1.26 & 1.40 & 1.17 & 1.89 & 0.65 & 1.98 & 1.12 & 1.38 & 1.24 \\
\hline \multicolumn{10}{|c|}{ Mexican Peso } \\
\hline Mean of profits & $3.62 \%$ & $31.94 \%$ & $0.51 \%$ & $18.68 \%$ & $-2.65 \%$ & $1.98 \%$ & $-2.64 \%$ & $8.27 \%$ & $-0.93 \%$ \\
\hline Volatility of profits & $7.28 \%$ & $13.96 \%$ & $9.61 \%$ & $8.53 \%$ & $6.34 \%$ & $8.10 \%$ & $6.11 \%$ & $4.91 \%$ & $5.11 \%$ \\
\hline Information ratio & 0.50 & 2.29 & 0.05 & 2.19 & -0.42 & 0.24 & -0.43 & 1.68 & -0.18 \\
\hline \multicolumn{10}{|c|}{ New Zealand Dollar } \\
\hline Mean of profits & $7.31 \%$ & $-1.86 \%$ & $18.91 \%$ & $-15.3 \%$ & $29.05 \%$ & $23.34 \%$ & $0.10 \%$ & $-12.7 \%$ & $8.45 \%$ \\
\hline Volatility of profits & $9.91 \%$ & $9.18 \%$ & $10.78 \%$ & $9.17 \%$ & $10.76 \%$ & $10.79 \%$ & $11.20 \%$ & $6.98 \%$ & $7.44 \%$ \\
\hline Information ratio & 0.74 & -0.20 & 1.75 & -1.66 & 2.70 & 2.16 & 0.01 & -1.81 & 1.14 \\
\hline \multicolumn{10}{|c|}{ South Africa Rand } \\
\hline Mean of profits & $16.97 \%$ & $2.78 \%$ & $15.19 \%$ & $56.92 \%$ & $13.66 \%$ & $33.91 \%$ & $-14.76 \%$ & $-0.53 \%$ & $12.96 \%$ \\
\hline Volatility of profits & $22.20 \%$ & $7.16 \%$ & $13.54 \%$ & $40.56 \%$ & $22.10 \%$ & $21.82 \%$ & $15.54 \%$ & $10.13 \%$ & $12.41 \%$ \\
\hline Information ratio & 0.76 & 0.39 & 1.12 & 1.40 & 0.62 & 1.55 & -0.95 & -0.05 & 1.04 \\
\hline \multicolumn{10}{|c|}{ Russian Ruble } \\
\hline Mean of profits & $6.10 \%$ & & $30.40 \%$ & $-1.49 \%$ & $-0.53 \%$ & $12.57 \%$ & $7.18 \%$ & $-3.47 \%$ & $2.99 \%$ \\
\hline Volatility of profits & $6.49 \%$ & & $16.61 \%$ & $1.67 \%$ & $1.59 \%$ & $3.10 \%$ & $3.74 \%$ & $3.04 \%$ & $6.48 \%$ \\
\hline Information ratio & 0.94 & & 1.83 & -0.89 & -0.33 & 4.06 & 1.92 & -1.14 & 0.46 \\
\hline \multicolumn{10}{|c|}{ An Equally Weighted Portfolio of Exotic Currencies } \\
\hline Mean of profits & $11.36 \%$ & $14.04 \%$ & $13.37 \%$ & $19.44 \%$ & $12.84 \%$ & $20.83 \%$ & $3.76 \%$ & $-0.01 \%$ & $1.39 \%$ \\
\hline Volatility of profits & $6.64 \%$ & $5.79 \%$ & $4.81 \%$ & $7.91 \%$ & $8.63 \%$ & $7.74 \%$ & $5.89 \%$ & $4.85 \%$ & $4.27 \%$ \\
\hline Information ratio & 1.71 & 2.43 & 2.78 & 2.46 & 1.49 & 2.69 & 0.64 & -0.00 & 0.33 \\
\hline
\end{tabular}




\section{EXHIBIT 4}

Average Annual Excess Returns on Exotic Currencies Relative to U.S. T-Bills, Leveraged Based on 12\% Volatility of Annual Excess Returns and Moving Average Rules

\begin{tabular}{lr}
\hline & $\mathbf{2 0 0 0 - 2 0 0 6}$ \\
\hline Brazilian real & $17.72 \%$ \\
Mexican Peso & $4.83 \%$ \\
New Zealand Dollar & $10.46 \%$ \\
South African Rand & $15.65 \%$ \\
Russian Ruble & $15.97 \%$ \\
\hline Portfolio & $21.36 \%$ \\
\hline
\end{tabular}

